\title{
Review
}

Folia Phoniatrica

et Logopaedica

\section{Reading in Autism Spectrum Disorders: A Literature Review}

\author{
Fernanda Dreux Miranda Fernandes ${ }^{a}$
}

Cibelle Albuquerque de La Higuera Amato $^{\text {b }}$ Carla Cardoso $^{d}$

Ana Luiza Gomes Pinto Navas ${ }^{c}$ Daniela Regina Molini-Avejonas ${ }^{a}$

a Department of Physical Therapy, Speech-Language Pathology and Audiology, and Occupational Therapy, School of Medicine, Universidade de São Paulo (FMUSP), ${ }^{b}$ Developmental Disorders Program, Centre for Health and Biological Sciences, Universidade Presbiteriana Mackenzie, and 'Santa Casa School of Health Sciences, São Paulo, and ${ }^{\mathrm{d}}$ Universidade do Estado da Bahia, Salvador, Brazil

\section{Key Words}

Autism spectrum disorders · Reading $\cdot$ Language $\cdot$

Intervention

\begin{abstract}
Objective: To review what the literature says about reading abilities of children on the autism spectrum (autism spectrum disorders, ASD) as well as to assess the results of intervention proposals. The broad ASD diagnosis used in the last decades and the resulting changes in the prevalence of these disorders have led to a relevant increase in the number of children diagnosed with ASD in the school system. The purpose of this review is to identify the different profiles of reading abilities shown by children with ASD described in the recent literature and the results of reported intervention methods. Methods: A review of the literature was conducted in the Web of Sciences and PubMed databases with the keywords 'autism' AND 'read*' and the filter 2010-2015. All articles published in the last 5 years focusing on description of and intervention for reading abilities in individuals with ASD were included. Review articles were excluded. Results: The selected 58 articles were divided into those that described reading abilities in individuals with ASD $(n=27)$ and those
\end{abstract}

that reported intervention procedures for reading development $(n=31)$. Conclusions: Direct comparisons and associations were prevented due to different inclusion criteria and lack of detailed information about intervention processes. We propose tentative conclusions that should be confirmed by further studies.

(c) 2016 S. Karger AG, Basel

\section{Introduction}

The increasing number of children with a diagnosis of autism spectrum disorders (ASD) in the school system demands consistent information about the characterization of their reading abilities and the results of different intervention alternatives.

ASD have been the focus of many studies based on several different perspectives. These may vary from genetic and neurologic correlates [1-4] to social and emotional impact [5-7], or educational issues [8, 9], family perspectives $[10,11]$ and different intervention proposals $[12,13]$.

The definitions and diagnostic criteria for ASD vary significantly in different studies $[14,15]$, and therefore the conclusions can hardly be compared or accumulated,

\section{KARGER 125}

(c) 2016 S. Karger AG, Base

$1021-7762 / 16 / 0674-0169 \$ 39.50 / 0$

E-Mail karger@karger.com

www.karger.com/fpl
Prof. Fernanda Dreux Miranda Fernandes

Department of Physical Therapy, Speech-Language Pathology and Audiology, and Occupational Therapy, School of Medicine

Universidade de São Paulo (FMUSP), Rua Cipotânea 51

Cidade Universitária, São Paulo, SP 05360-160 (Brazil), E-Mail fernandadreux@usp.br 
providing consistent data. The changes in the definition of what should be included within the autism spectrum are just one of the many variations that must be considered $[16,17]$.

The changes implemented in the DSM- 5 classification criteria will probably lead to different groups of individuals receiving the diagnosis of ASD $[18,19]$. Therefore, comparing the results of studies conducted before and after these changes may become even more complicated. It can be assumed that the vast majority of the subjects in studies published until 2015 were diagnosed according to the DSM-IV criteria. However, it is virtually impossible to determine a time frame from which all papers refer to subjects diagnosed according to the DSM-5 criteria.

On the other hand, the broad ASD diagnosis used in the last three decades and the resulting changes in the prevalence of these disorders $[20,21]$ have led to a relevant increase in the number of children diagnosed with ASD in the school system [22].

Regarding reading abilities, studies should describe whether they refer to decoding, such as performance in tasks of word recognition performance, or in a broader sense to word reading comprehension [23]. Children with ASD are often characterized as showing precocious word reading abilities [24], but even though these children may have good decoding skills, comprehension is impaired in most cases.

Considering these aspects, it is relevant to know, at this point, what the recent literature describes about reading abilities in children with ASD and the intervention approaches proposed to improve such skills. Therefore, a literature review was performed with the purpose to address the questions: 'do children with autism have specific reading impairments?' and 'do interventions with focus on reading abilities of children with autism have positive results?'.

\section{Objectives}

The purpose of this review was to identify the different profiles of reading abilities of children with ASD and the results of different intervention methods reported in the literature.

\section{Search Strategy}

A review of the literature was conducted to answer the questions stated above. The Web of Sciences (WoS) and PubMed (PM) databases were searched with the keywords 'autism' AND 'read*' with the filter 2010-2015.

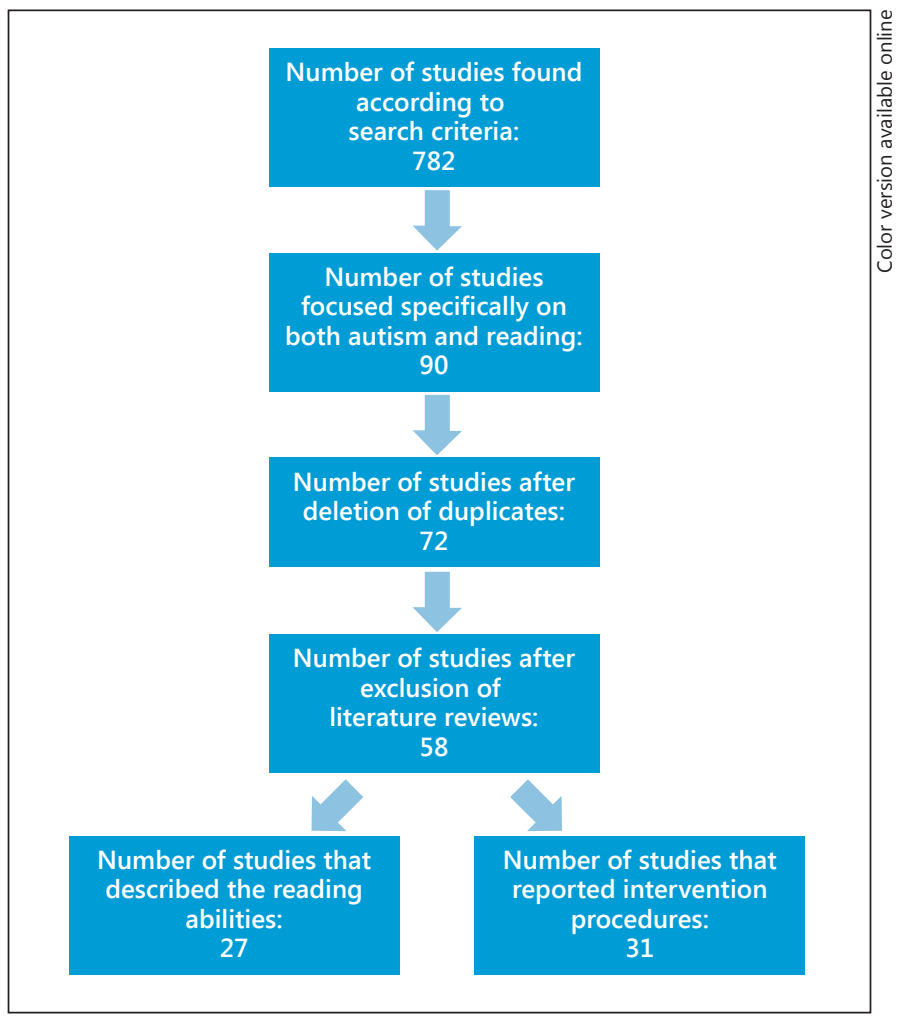

Fig. 1. Search and selection process.

Inclusion criteria were: articles published in the last 5 years in peer-reviewed journals indexed in WoS and PM databases with the focus on a description of reading abilities and intervention with individuals with ASD. Review articles were excluded.

In order to obtain an overview of the available information about the characterization of reading abilities and intervention proposals no further criteria were applied in the selection of the reviewed papers.

\section{Results}

The first search resulted in 782 articles; 604 in WoS and 178 in PM. The initial analysis aimed to determine which of them focused specifically on both autism and reading. This process resulted in 58 papers in WoS and 32 in PM, a total of 90 articles. They were further analyzed to eliminate duplicates (i.e. articles that were included both in WoS and PM) and publications that did not have enough data; this search resulted in 72 articles that were analyzed according to their content. Among these, 14 articles were reports on literature reviews and were, there- 
fore, excluded. The remaining 58 were divided into two categories: (a) those that described the reading abilities of individuals with ASD $(n=27)$ and $(b)$ those that reported intervention procedures towards reading development $(\mathrm{n}=31)$ (fig. 1). Further inspection of the articles helped specifying the details of each study, number of participants, measures of literacy skills used, and main conclusions. The results are presented in tables 1 and 2 .

It can be observed that the number of participants in each study varied significantly. There are several papers describing studies with a relatively large numbers (59\% of them report studies with more than 20 participants), some single-case studies (7\%), and 4 studies that did not report the number of subjects (14\%). Only $11 \%$ of 27 articles described studies with adults.

Regarding the type of measures used to evaluate literacy skills, most studies (44\%) focused on single-word reading and text comprehension measures, some (29\%) assessed cognitive abilities that are related to reading such as memory and oral language skills, whereas only 2 studies investigated spelling skills in this specific population.

Although the inclusion criteria for the participants in each study are not equivalent across the different papers, thus preventing a true meta-analysis, some tentative conclusions can be drawn.

- Performance in single-word reading tasks is better than reading comprehension.

- The oral language level is associated with reading comprehension.

- Persons with ASD have difficulties with reading comprehension despite eventually good or intact decoding skills.

- There is no confirmation of the weak central coherence hypothesis; it seems that the lack of association between meaning and word recognition is based on other factors.

- Nonverbal social and cognitive abilities are associated with reading comprehension and reading performance.

- Phonological processing seems to be less associated with reading comprehension performance than semantics and syntactic knowledge.

Contrary to what could be observed in articles describing reading abilities of persons with ASD, most of the papers describing intervention procedures had a small number of subjects [22 papers (70\%) had 6 participants or less]. In total, these papers reported on 62 children and 5 adults. Six articles reported interventions with more than 18 participants, leading to a total of 143 children in these larger-number studies.
The intervention procedures described can be divided in two groups: those aiming to improve single-word reading and those directed to reading comprehension. Behavioral techniques are the basis for the strategies used in studies that focused on improving single-word reading. The conclusions of these articles imply that not all progress was generalized or maintained after the end of the training programs. The papers reporting programs for enhancing reading comprehension describe different approaches such as computer-assisted instruction, direct instruction, talking about a book, graphic organizers, story maps and prompting. Generalization to other abilities and stability of improvement were reported by these studies.

Three other articles refer to suggestions of intervention strategies such as scaffolding and the use of software designed to improve reading comprehension. These approaches are described as flexible, allowing one-to-one adaptations.

\section{Conclusion}

Characteristics of the reading process of persons with ASD were described in 27 articles that included 1,490 individuals. Direct comparisons and associations are prevented by the different inclusion criteria used in the different studies. However, it is possible to propose some preliminary conclusions that should be confirmed by further studies. Reading comprehension seems to be more associated with semantic and syntactic abilities in oral language than with phonological development. Decoding skills, apparently, are not directly associated with reading comprehension, thus leading to better performance in single-word reading tests than in reading comprehension. Nonverbal social and cognitive abilities seem to be associated with reading comprehension and reading performance, especially in what refers to the association of meaning to a word.

Intervention proposals regarding reading abilities of persons with ASD are reported in 31 articles that refer to a total of 210 subjects, including just 5 adults. Not all studies provide the detailed descriptions of the intervention procedures that would be necessary to make comparisons and associations between them. Very few studies include information about the duration of the intervention and the prior training of the therapists. Therefore, any conclusion about the reasons for the reported results would be premature. Better and more stable results are described by the articles that report interventions focused towards 
Table 1. Articles about reading characteristics of persons with ASD

\begin{tabular}{|c|c|c|c|c|}
\hline Authors & Title & Reference & Participants & Conclusions \\
\hline $\begin{array}{l}\text { Au-Yeung SK, } \\
\text { Kaakinen JK, } \\
\text { Liversedge SP, et al. }\end{array}$ & $\begin{array}{l}\text { Processing written irony in } \\
\text { autism spectrum disorder: } \\
\text { an eye-movement study }\end{array}$ & $\begin{array}{l}\text { Autism Res 2015, } \\
\text { DOI: 10.1002/aur.1490 }\end{array}$ & Adults $^{\mathrm{a}}$ & $\begin{array}{l}\text { Participants with ASD and controls had the } \\
\text { same performance while reading ironic } \\
\text { nonironic texts. Participants of both groups } \\
\text { required more time to read ironic statements. }\end{array}$ \\
\hline $\begin{array}{l}\text { Wei X, Christiano E, } \\
\text { Yu W, et al. }\end{array}$ & $\begin{array}{l}\text { Reading and math achievement } \\
\text { profiles and longitudinal growth } \\
\text { trajectories of children with } \\
\text { autism spectrum disorder }\end{array}$ & Autism 2015;19:200-210 & 130 children & $\begin{array}{l}\text { Children with hyperlexia had slower } \\
\text { improvement in conversational skills when } \\
\text { compared with children with hypercalculia. }\end{array}$ \\
\hline $\begin{array}{l}\text { Davidson } \mathrm{M} \text {, } \\
\text { Weismer S }\end{array}$ & $\begin{array}{l}\text { Characterization and prediction } \\
\text { of early reading abilities in } \\
\text { children on the autism spectrum }\end{array}$ & $\begin{array}{l}\text { J Autism Dev Disord } \\
2014 ; 44: 828-845\end{array}$ & 94 children & $\begin{array}{l}\text { Children had reading levels within the normal } \\
\text { range. Nonverbal cognition and expressive } \\
\text { language abilities predicted reading } \\
\text { performance. }\end{array}$ \\
\hline $\begin{array}{l}\text { Lucas R, } \\
\text { Norbury C }\end{array}$ & $\begin{array}{l}\text { Levels of text comprehension in } \\
\text { children with autism spectrum } \\
\text { disorders (ASD): the influence } \\
\text { of language phenotype }\end{array}$ & $\begin{array}{l}\text { J Autism Dev Disord } \\
2014 ; 44: 2756-2768\end{array}$ & 80 children & $\begin{array}{l}\text { Literacy competence cannot be predicted just } \\
\text { by word reading. Children with oral language } \\
\text { impairment are more likely to present } \\
\text { difficulties in learning to read text (despite } \\
\text { their abilities to read single words). }\end{array}$ \\
\hline $\begin{array}{l}\text { Adlof S, Klusek J, } \\
\text { Shinkareva S, et al. }\end{array}$ & $\begin{array}{l}\text { Phonological awareness and } \\
\text { reading in boys with fragile } \mathrm{X} \\
\text { syndrome }\end{array}$ & $\begin{array}{l}\text { J Child Psychol Psychiatry } \\
\text { 2015;56:30-39 }\end{array}$ & 54 children & $\begin{array}{l}\text { Phonological and nonverbal cognitive skills } \\
\text { were similar and had similar relationships } \\
\text { with reading. }\end{array}$ \\
\hline $\begin{array}{l}\text { Troyb E, Orinstein } \\
\text { A, Tyson K, et al. }\end{array}$ & $\begin{array}{l}\text { Academic abilities in children } \\
\text { and adolescents with a history of } \\
\text { autism spectrum disorders who } \\
\text { have achieved optimal outcomes }\end{array}$ & Autism 2014;18:233-243 & 41 children & $\begin{array}{l}\text { Children with high-functioning autism } \\
\text { presented lower scores in reading } \\
\text { comprehension and mathematical problem } \\
\text { solving. }\end{array}$ \\
\hline Cronin K & $\begin{array}{l}\text { The relationship among oral } \\
\text { language, decoding skills, and } \\
\text { reading comprehension in } \\
\text { children with autism }\end{array}$ & $\begin{array}{l}\text { Exceptionality } \\
2014 ; 22: 141-157\end{array}$ & 13 children & $\begin{array}{l}\text { Identified a significant relationship between } \\
\text { reading ability and semantics but none with } \\
\text { phonology. Semantics and syntax are also } \\
\text { related to reading comprehension. }\end{array}$ \\
\hline $\begin{array}{l}\text { Inoue K, Wada M, } \\
\text { Natsuyama T, et al. }\end{array}$ & $\begin{array}{l}\text { The feature of high reading ability } \\
\text { in high-functioning pervasive } \\
\text { develop mental disorders of } \\
\text { childhood: analysis of the K-ABC } \\
\text { and WISC-3rd assessment }\end{array}$ & $\begin{array}{l}\text { Res Autism Spectr Disord } \\
2014 ; 8: 25-30\end{array}$ & $\begin{array}{l}60 \text { children } \\
(35 \text { ASD })\end{array}$ & $\begin{array}{l}\text { Results suggest that children with high } \\
\text { functioning ASD have high reading abilities } \\
\text { but read words like symbols but do not use } \\
\text { semantics or context to extract meaning to } \\
\text { infer and comprehend. }\end{array}$ \\
\hline $\begin{array}{l}\text { Cardoso-Martins C, } \\
\text { Gonçalves D, } \\
\text { de Magalhães C }\end{array}$ & $\begin{array}{l}\text { What are the mechanisms behind } \\
\text { exceptional word reading ability } \\
\text { in hyperlexia? Evidence from a } \\
\text { 4-year-old hyperlexic boy's } \\
\text { invented spellings }\end{array}$ & $\begin{array}{l}\text { J Autism Dev Disord } \\
\text { 2013;43:3001-3003 }\end{array}$ & $1 \mathrm{ch}$ & $\begin{array}{l}\text { Analysis of the spelling errors of children with } \\
\text { hyperlexia and ASD can provide important } \\
\text { information about how they learn to read and } \\
\text { process graphophonemic correspondence. }\end{array}$ \\
\hline $\begin{array}{l}\text { Jacobs D, } \\
\text { Richdale A }\end{array}$ & $\begin{array}{l}\text { Predicting literacy in children } \\
\text { with a high-functioning autism } \\
\text { spectrum disorder }\end{array}$ & $\begin{array}{l}\text { Res Dev Disabil } \\
\text { 2013;34:2379-2390 }\end{array}$ & $\begin{array}{l}84 \text { children } \\
(42 \text { ASD) }\end{array}$ & $\begin{array}{l}\text { For young children with high-functioning } \\
\text { ASD, phonological processing and oral } \\
\text { language may predict literacy performance. }\end{array}$ \\
\hline $\begin{array}{l}\text { Arciuli J, Stevens K, } \\
\text { Trembath D, et al. }\end{array}$ & $\begin{array}{l}\text { The relationship between parent } \\
\text { report of adaptive behavior and } \\
\text { direct assessment of reading } \\
\text { ability in children with autism } \\
\text { spectrum disorder }\end{array}$ & $\begin{array}{l}\text { J Speech Lang Hear Res } \\
\text { 2013;56:1837-1844 }\end{array}$ & 21 children & $\begin{array}{l}\text { As other characteristics of children with ASD, } \\
\text { literacy levels vary among them and some } \\
\text { have clear difficulties with reading. Adaptive } \\
\text { behavior, as reported by parents, is associated } \\
\text { with reading abilities. }\end{array}$ \\
\hline $\begin{array}{l}\text { Brock J, } \\
\text { Bzishvili S }\end{array}$ & $\begin{array}{l}\text { Deconstructing Frith and } \\
\text { Snowling's homograph-reading } \\
\text { task: implications for autism } \\
\text { spectrum disorders }\end{array}$ & $\begin{array}{l}\text { Q J Exp Psychol (Hove) } \\
\text { 2013;66:1764-1773 }\end{array}$ & Adults $^{\mathrm{a}}$ & $\begin{array}{l}\text { Several factors that affect the reading } \\
\text { performance of adults with ASD were } \\
\text { identified. They do not confirm the weak } \\
\text { central coherence hypothesis. }\end{array}$ \\
\hline $\begin{array}{l}\text { Ricketts J, Jones C, } \\
\text { Happé F, et al. }\end{array}$ & $\begin{array}{l}\text { Reading comprehension in autism } \\
\text { spectrum disorders: the role of } \\
\text { oral language and social } \\
\text { functioning }\end{array}$ & $\begin{array}{l}\text { J Autism Dev Disord } \\
\text { 2013;43:807-816 }\end{array}$ & 100 children & $\begin{array}{l}\text { Word recognition and oral language may } \\
\text { explain the variances in reading } \\
\text { comprehension. Social behavior and social } \\
\text { cognition predict reading comprehension. }\end{array}$ \\
\hline
\end{tabular}


Table 1 (continued)

\begin{tabular}{|c|c|c|c|c|}
\hline Authors & Title & Reference & Participants & Conclusions \\
\hline $\begin{array}{l}\text { Tsai A, } \\
\text { Savostyanov A, } \\
\text { Wu A, et al. }\end{array}$ & $\begin{array}{l}\text { Recognizing syntactic errors in } \\
\text { Chinese and English sentences: } \\
\text { brain electrical activity in } \\
\text { Asperger's syndrome }\end{array}$ & $\begin{array}{l}\text { Res Autism Spectr Disord } \\
\text { 2013;7:889-905 }\end{array}$ & $\begin{array}{l}31 \text { adults } \\
(10 \text { ASD) }\end{array}$ & $\begin{array}{l}\text { In ASD and control groups matched for } \\
\text { reading competence, it seems that ASD } \\
\text { individuals have more difficulty in brain } \\
\text { organization of the semantic and syntactic } \\
\text { processes. }\end{array}$ \\
\hline $\begin{array}{l}\text { Baliousis } \mathrm{M} \text {, } \\
\text { Vollm B, Banerjee P, } \\
\text { et al. }\end{array}$ & $\begin{array}{l}\text { Autistic spectrum disorder, } \\
\text { personality disorder and } \\
\text { reading disability: a complex } \\
\text { case that falls between the cracks? }\end{array}$ & $\begin{array}{l}\text { J Forens Psychiatry } \\
\text { Psychol 2013;24:286-292 }\end{array}$ & 1 adult & $\begin{array}{l}\text { Describes the case of an individual convicted } \\
\text { for violent offense that had extreme } \\
\text { difficulties in receiving adequate service due } \\
\text { to autism, personality disorder and dyslexia. }\end{array}$ \\
\hline $\begin{array}{l}\text { Hellinckx T, Roeyers } \\
\text { H, Van Waelvelde H }\end{array}$ & $\begin{array}{l}\text { Predictors of handwriting in } \\
\text { children with autism spectrum } \\
\text { disorder }\end{array}$ & $\begin{array}{l}\text { Res Autism Spectr Disord } \\
\text { 2013;7:176-186 }\end{array}$ & $\begin{array}{l}131 \text { children } \\
\text { (70 ASD) }\end{array}$ & $\begin{array}{l}\text { Reading abilities and fine motor skills were } \\
\text { associated with handwriting speed while } \\
\text { gender and visual motor integration impacted } \\
\text { handwriting quality. }\end{array}$ \\
\hline $\begin{array}{l}\text { Williamson P, } \\
\text { Carnahan C, Jacobs J }\end{array}$ & $\begin{array}{l}\text { Reading comprehension profiles } \\
\text { of high-functioning students on } \\
\text { the autism spectrum: a grounded } \\
\text { theory }\end{array}$ & $\begin{array}{l}\text { Except Child 2012;78:449- } \\
469\end{array}$ & 13 children & $\begin{array}{l}\text { Approach based on the constructivist theory } \\
\text { to study influences on reading comprehension } \\
\text { of children with ASD. }\end{array}$ \\
\hline Treffert D & $\begin{array}{l}\text { Hyperlexia III: separating } \\
\text { 'autistic-like' behaviors from } \\
\text { autistic disorder; assessing } \\
\text { children who read early or } \\
\text { speak late }\end{array}$ & $\begin{array}{l}\text { WMJ 2011;110:281-286; } \\
\text { quiz } 287\end{array}$ & Children $^{\mathrm{a}}$ & $\begin{array}{l}\text { Describes different conditions within the } \\
\text { autism spectrum and the characteristics as } \\
\text { hyperlexia and language delay. }\end{array}$ \\
\hline Whalon K, Hart J & $\begin{array}{l}\text { Children with autism spectrum } \\
\text { disorder and literacy instruction: } \\
\text { an exploratory study of } \\
\text { elementary inclusive settings }\end{array}$ & $\begin{array}{l}\text { Remedial Spec Educ } \\
\text { 2011;32:243-255 }\end{array}$ & 3 children & $\begin{array}{l}\text { The study shows the challenges faced by } \\
\text { children with ASD in literacy instruction: few } \\
\text { experiences of comprehension instruction is } \\
\text { one of the most relevant. }\end{array}$ \\
\hline $\begin{array}{l}\text { Norbury C, } \\
\text { Nation K }\end{array}$ & $\begin{array}{l}\text { Understanding variability in } \\
\text { reading comprehension in } \\
\text { adolescents with autism spectrum } \\
\text { disorders: interactions with } \\
\text { language status and decoding skill }\end{array}$ & $\begin{array}{l}\text { Sci Stud Read 2011;15:191- } \\
210\end{array}$ & 27 children & $\begin{array}{l}\text { Poor structural language skills were associated } \\
\text { with difficulties in comprehension. } \\
\text { Performance in single-word reading was } \\
\text { better. Decoding and comprehension seem to } \\
\text { interfere with reading abilities. }\end{array}$ \\
\hline $\begin{array}{l}\text { Asberg J, Kopp S, } \\
\text { Berg-Kelly K, et al. }\end{array}$ & $\begin{array}{l}\text { Reading comprehension, word } \\
\text { decoding and spelling in girls } \\
\text { with autism spectrum disorders } \\
\text { (ASD) or attention-deficit/ } \\
\text { hyperactivity disorder (ADHD): } \\
\text { performance and predictors }\end{array}$ & $\begin{array}{l}\text { Int J Lang Commun } \\
\text { Disord 2010;45:61-71 }\end{array}$ & $\begin{array}{l}110 \text { children } \\
(20 \text { ASD })\end{array}$ & $\begin{array}{l}\text { Girls with typical development, with } \\
\text { attention-deficit/ hyperactivity disorder and } \\
\text { with ASD performed similarly in the literacy } \\
\text { tests, but girls with autism had important } \\
\text { difficulties in reading comprehension despite } \\
\text { decoding and vocabulary training. }\end{array}$ \\
\hline $\begin{array}{l}\text { Cardoso-Martins C, } \\
\text { da Silva J }\end{array}$ & $\begin{array}{l}\text { Cognitive and language correlates } \\
\text { of hyperlexia: evidence from } \\
\text { children with autism spectrum } \\
\text { disorders }\end{array}$ & $\begin{array}{l}\text { Read Writ 2010;23:129- } \\
145\end{array}$ & 18 children & $\begin{array}{l}\text { Reading by hyperlexic children with ASD } \\
\text { apparently result from computing letter- } \\
\text { sound relations implicitly and using statistical } \\
\text { learning. These children had poor } \\
\text { performance on phonological awareness and } \\
\text { on phoneme-grapheme tasks. }\end{array}$ \\
\hline $\begin{array}{l}\text { Huemer S, } \\
\text { Mann V }\end{array}$ & $\begin{array}{l}\text { A comprehensive profile of } \\
\text { decoding and comprehension } \\
\text { in autism spectrum disorders }\end{array}$ & $\begin{array}{l}\text { J Autism Dev Disord } \\
2010 ; 40: 485-493\end{array}$ & 384 children & $\begin{array}{l}\text { Results indicate no association between } \\
\text { decoding and comprehension. Relatively } \\
\text { intact decoding skills occurred along with low } \\
\text { comprehension. }\end{array}$ \\
\hline $\begin{array}{l}\text { St Clair M, Durkin K, } \\
\text { Conti-Ramsden G, } \\
\text { et al. }\end{array}$ & $\begin{array}{l}\text { Growth of reading skills in } \\
\text { children with a history of specific } \\
\text { language impairment: the role of } \\
\text { autistic symptomatology and } \\
\text { language-related abilities }\end{array}$ & $\begin{array}{l}\text { Br J Dev Psychol } \\
\text { 2010;28(pt 1):109-131 }\end{array}$ & Children $^{\mathrm{a}}$ & $\begin{array}{l}\text { Reading skills are associated with language } \\
\text { abilities. Individuals with SLI and ASD had } \\
\text { adequate reading performance. There is a } \\
\text { significant gap between what ASD children } \\
\text { can read and what they can understand. }\end{array}$ \\
\hline $\begin{array}{l}\text { Caruana N, } \\
\text { Brock J }\end{array}$ & $\begin{array}{l}\text { No association between autistic } \\
\text { traits and contextual influences } \\
\text { on eye-movements during reading }\end{array}$ & PeerJ 2014;2:e466 & 71 adults & $\begin{array}{l}\text { No support to the weak central coherence } \\
\text { hypothesis nor to the 'comprehension } \\
\text { monitoring' alternative. }\end{array}$ \\
\hline
\end{tabular}


Table 1 (continued)

\begin{tabular}{|c|c|c|c|c|}
\hline Authors & Title & Reference & Participants & Conclusions \\
\hline $\begin{array}{l}\text { Miniscalco C, } \\
\text { Sandberg A }\end{array}$ & $\begin{array}{l}\text { Basic reading skills in Swedish } \\
\text { children with late developing } \\
\text { language and with or without } \\
\text { autism spectrum disorder or } \\
\text { ADHD }\end{array}$ & $\begin{array}{l}\text { Res Dev Disabil } \\
\text { 2010;31:1054-1061 }\end{array}$ & $\begin{array}{l}21 \text { children } \\
\text { (5 ASD) }\end{array}$ & $\begin{array}{l}\text { There were significant differences in } \\
\text { phonological and grammatical awareness, } \\
\text { color naming and word memory between } \\
\text { children with ASD and normal-developing } \\
\text { children. }\end{array}$ \\
\hline
\end{tabular}

${ }^{a}$ Number of subjects not indicated.

Table 2. Articles describing intervention proposals regarding reading abilities of persons with ASD

\begin{tabular}{|c|c|c|c|c|}
\hline Authors & Title & Reference & Participants & Proposals and Conclusions \\
\hline $\begin{array}{l}\text { Knight V, Wood C, } \\
\text { Spooner F, et al. }\end{array}$ & $\begin{array}{l}\text { An exploratory study using science } \\
\text { eTexts with students with autism } \\
\text { spectrum disorders }\end{array}$ & $\begin{array}{l}\text { Focus Autism Other Dev } \\
\text { Disabl 2015;30:86-99 }\end{array}$ & Children $^{a}$ & $\begin{array}{l}\text { Book Builder is a tool to facilitate reading for } \\
\text { children with autism. Teachers and students } \\
\text { reported satisfaction. }\end{array}$ \\
\hline $\begin{array}{l}\text { Williamson P, } \\
\text { Carnahan C, Birri N, } \\
\text { et al. }\end{array}$ & $\begin{array}{l}\text { Improving comprehension of } \\
\text { narrative using character event } \\
\text { maps for high school students with } \\
\text { autism spectrum disorder }\end{array}$ & $\begin{array}{l}\text { J Spec Educ 2015;49:28- } \\
38\end{array}$ & 3 children & $\begin{array}{l}\text { Studied the effectiveness of an intervention } \\
\text { package that included scaffolded completion } \\
\text { to improve text comprehension. There were } \\
\text { changes in scores. }\end{array}$ \\
\hline $\begin{array}{l}\text { Ricketts J, Dockrell J, } \\
\text { Charman T, et al. }\end{array}$ & $\begin{array}{l}\text { Do children with specific language } \\
\text { impairment and autism spectrum } \\
\text { disorders benefit from the presence } \\
\text { of orthography when learning new } \\
\text { spoken words? }\end{array}$ & $\begin{array}{l}\text { J Exp Child Psychol } \\
2015 ; 134: 43-61\end{array}$ & 54 children & $\begin{array}{l}\text { The study provides evidence that the presence } \\
\text { of orthographic cues can support interventions } \\
\text { that emphasize the orthographic form. }\end{array}$ \\
\hline $\begin{array}{l}\text { Murdaugh D, } \\
\text { Deshpande H, Kana R }\end{array}$ & $\begin{array}{l}\text { The impact of reading intervention } \\
\text { on brain responses underlying } \\
\text { language in children with autism }\end{array}$ & $\begin{array}{l}\text { Autism Res 2015, DOI: } \\
\text { 10.1002/aur.1503 }\end{array}$ & 15 children & $\begin{array}{l}\text { The findings of this study suggest the potential } \\
\text { of a strength-based reading intervention in } \\
\text { changing brain responses and facilitating } \\
\text { better reading comprehension in ASD } \\
\text { children. }\end{array}$ \\
\hline $\begin{array}{l}\text { Morlock L, Reynolds } \\
\text { J, Fischer S, et al. }\end{array}$ & $\begin{array}{l}\text { Video modeling and word } \\
\text { identification in adolescents with } \\
\text { Autism Spectrum Disorder }\end{array}$ & $\begin{array}{l}\text { Child Lang Teach Ther } \\
\text { 2015;31:101-111 }\end{array}$ & 3 children & $\begin{array}{l}\text { Evidence-based intervention using video } \\
\text { modeling was effective in improving word } \\
\text { recognition and reading. }\end{array}$ \\
\hline Zhang D, Spencer V & $\begin{array}{l}\text { Addressing the needs of students } \\
\text { with autism and other disabilities in } \\
\text { China: perspectives from the field }\end{array}$ & $\begin{array}{l}\text { Intl J Disabil Dev Educ } \\
2015 ; 62: 168-181\end{array}$ & 2 children & $\begin{array}{l}\text { The qualitative study identified main areas of } \\
\text { attention: teacher recruitment and training, } \\
\text { curriculum methodology and parental } \\
\text { involvement. }\end{array}$ \\
\hline $\begin{array}{l}\text { Leytham P, Pierce T, } \\
\text { Baker J, et al. }\end{array}$ & $\begin{array}{l}\text { Evaluation of the nonverbal } \\
\text { approach for two } 12 \text { to } 13 \text {-year-old } \\
\text { students with ASD }\end{array}$ & $\begin{array}{l}\text { Res Autism Spectr } \\
\text { Disord 2015;9:68-76 }\end{array}$ & 2 children & $\begin{array}{l}\text { Ten words were trained in } 20 \text { sessions with the } \\
\text { Nonverbal Reading Approach method. Results } \\
\text { are reported effective. }\end{array}$ \\
\hline $\begin{array}{l}\text { Reutebuch C, El Zein } \\
\text { F, Kim M, et al. }\end{array}$ & $\begin{array}{l}\text { Investigating a reading } \\
\text { comprehension intervention for } \\
\text { high school children with autism } \\
\text { spectrum disorder: a pilot study }\end{array}$ & $\begin{array}{l}\text { Res Autism Spectr } \\
\text { Disord 2015;9:96-111 }\end{array}$ & $\begin{array}{l}6 \text { children } \\
\text { ( } 3 \text { ASD) }\end{array}$ & $\begin{array}{l}\text { The Collaborative Strategic Reading - High } \\
\text { School was adapted and used in } 41 \text { sessions. } \\
\text { Increases in comprehension and interactions } \\
\text { were noted. }\end{array}$ \\
\hline
\end{tabular}


Table 2 (continued)

\begin{tabular}{|c|c|c|c|c|}
\hline Authors & Title & Reference & Participants & Proposals and Conclusions \\
\hline $\begin{array}{l}\text { Pennington R, } \\
\text { Collins B, Stenhoff D, } \\
\text { et al. }\end{array}$ & $\begin{array}{l}\text { Using simultaneous prompting and } \\
\text { computer-assisted instruction to } \\
\text { teach narrative writing skills to } \\
\text { students with autism }\end{array}$ & $\begin{array}{l}\text { Educ Train Autism Dev } \\
\text { Disabil 2014;49:396-414 }\end{array}$ & 5 children & $\begin{array}{l}\text { Simultaneous prompting and computer- } \\
\text { assisted instruction were effective in } \\
\text { improving the participant's performance in } \\
\text { story reading skills. Non-targeted reading } \\
\text { skills were also improved. }\end{array}$ \\
\hline Lucas R, Norbury C & $\begin{array}{l}\text { Orthography facilitates vocabulary } \\
\text { learning for children with autism } \\
\text { spectrum disorders }\end{array}$ & $\begin{array}{l}\text { Q J of Exp Psychol } \\
\text { (Hove) 2014;67:1317- } \\
1334\end{array}$ & 20 children & $\begin{array}{l}\text { Vocabulary learning associated with reading } \\
\text { the single low-frequency words. Orthography } \\
\text { facilitated vocabulary learning. }\end{array}$ \\
\hline $\begin{array}{l}\text { Gonzalez-Navarro A, } \\
\text { Freire-Prudencio S, } \\
\text { Gil D, et al. }\end{array}$ & $\begin{array}{l}\text { FIRST: a tool for facilitating } \\
\text { reading comprehension in high- } \\
\text { functioning autism spectrum } \\
\text { disorder (in Spanish) }\end{array}$ & $\begin{array}{l}\text { Rev Neurol } \\
\text { 2014;58:S129-S135 }\end{array}$ & None & $\begin{array}{l}\text { Software was developed not just designed for } \\
\text { people with ASD but with people with ASD. } \\
\text { The tool must be flexible and facilitate } \\
\text { customized use. }\end{array}$ \\
\hline $\begin{array}{l}\text { Grindle C, Hughes J, } \\
\text { Saville M, et al. }\end{array}$ & $\begin{array}{l}\text { Teaching early reading skills to } \\
\text { children with autism using Mimio- } \\
\text { Sprout early reading }\end{array}$ & $\begin{array}{l}\text { Behav Interv } \\
2014 ; 28: 203-224\end{array}$ & 4 children & $\begin{array}{l}\text { The ABA program in a school setting has } \\
\text { shown improvement in word recognition even } \\
\text { in children with } 14 \text { months. }\end{array}$ \\
\hline $\begin{array}{l}\text { El Zein F, Solis M, } \\
\text { Lang R, et al. }\end{array}$ & $\begin{array}{l}\text { Embedding perseverative interest of } \\
\text { a child with autism in text may } \\
\text { result in improved reading } \\
\text { comprehension: a pilot study }\end{array}$ & $\begin{array}{l}\text { Dev Neurorehabil 2015, } \\
\text { Epub ahead of print }\end{array}$ & 1 child & $\begin{array}{l}\text { Embedding the perseverative interest of a child } \\
\text { with ASD with readings may lead to more } \\
\text { adequate answers in reading comprehension. }\end{array}$ \\
\hline $\begin{array}{l}\text { Goh S, Whitaker A, } \\
\text { Feldman J, et al. }\end{array}$ & $\begin{array}{l}\text { Teaching non-verbal children with } \\
\text { autistic disorder to read and write: } \\
\text { a pilot study }\end{array}$ & $\begin{array}{l}\text { Int J Dev Disabil } \\
\text { 2013;59:95-107 }\end{array}$ & 18 children & $\begin{array}{l}\text { Innovative curriculum with one-to-one } \\
\text { instruction in reading and writing. } \\
\text { Participants were tested before and after } \\
\text { intervention. All participants showed } \\
\text { improvement in the skills they were trained. }\end{array}$ \\
\hline Bethune K, Wood CL & $\begin{array}{l}\text { Effects of wh-question graphic } \\
\text { organizers on reading } \\
\text { comprehension skills of students } \\
\text { with autism spectrum disorders }\end{array}$ & $\begin{array}{l}\text { Educ Train Autism Dev } \\
\text { Disabil 2013;48:236-244 }\end{array}$ & 3 children & $\begin{array}{l}\text { Used graphic organizers to improve wh- } \\
\text { questions comprehension in reading tasks. } \\
\text { Accuracy of answers was improved. }\end{array}$ \\
\hline Akcin $\mathrm{N}$ & $\begin{array}{l}\text { Comparison of two instructional } \\
\text { strategies for students with autism } \\
\text { to read sight words }\end{array}$ & $\begin{array}{l}\text { Eurasian J Educ Res } \\
\text { 2013;13:85-106 }\end{array}$ & 3 children & $\begin{array}{l}\text { Five-word set for each teaching strategy (con- } \\
\text { stant time delay and stimulus fading). All } \\
\text { target words were acquired. Constant time } \\
\text { delay was more effective in terms of number of } \\
\text { trials. }\end{array}$ \\
\hline $\begin{array}{l}\text { Flores M, Nelson C, } \\
\text { Hinton V, et al. }\end{array}$ & $\begin{array}{l}\text { Teaching reading comprehension } \\
\text { and language skills to students with } \\
\text { autism spectrum disorders and } \\
\text { developmental disabilities using } \\
\text { direct instruction }\end{array}$ & $\begin{array}{l}\text { Educ Train Autism Dev } \\
\text { Disabil 2013;48:41-48 }\end{array}$ & 18 children & $\begin{array}{l}\text { The study demonstrated that direct instruction } \\
\text { is an effective model of intervention in reading } \\
\text { comprehension for students with ASD. }\end{array}$ \\
\hline $\begin{array}{l}\text { Tanji T, Takahashi K, } \\
\text { Noro F }\end{array}$ & $\begin{array}{l}\text { Teaching generalized reading and } \\
\text { spelling to children with autism }\end{array}$ & $\begin{array}{l}\text { Res Autism Spectr } \\
\text { Disord 2013;7:276-287 }\end{array}$ & 3 children & $\begin{array}{l}\text { Training on generalization of reading and } \\
\text { spelling skills with matching-to-sample } \\
\text { strategy. Two participants improved. }\end{array}$ \\
\hline Mucchetti C & $\begin{array}{l}\text { Adapted shared reading at school } \\
\text { for minimally verbal students with } \\
\text { autism }\end{array}$ & $\begin{array}{l}\text { Autism 2013;17:358- } \\
372\end{array}$ & 4 children & $\begin{array}{l}\text { Teachers and students read a book and talked } \\
\text { about it. All students showed improvement in } \\
\text { reading comprehension. }\end{array}$ \\
\hline $\begin{array}{l}\text { Crowley K, } \\
\text { McLaughlin T, } \\
\text { Kahn R }\end{array}$ & $\begin{array}{l}\text { Using direct instruction flashcards } \\
\text { and reading racetracks to improve } \\
\text { sight word recognition of two } \\
\text { elementary students with autism }\end{array}$ & $\begin{array}{l}\text { J Dev Phys Disabil } \\
\text { 2013;25:297-311 }\end{array}$ & 2 children & $\begin{array}{l}\text { Direct Instruction flashcards and reading } \\
\text { racetracks were used to improve reading of } \\
\text { sight words in } 2 \text { children with ASD. They } \\
\text { showed to be effective for both participants. }\end{array}$ \\
\hline $\begin{array}{l}\text { Taylor B, DeQuinzio J, } \\
\text { Stine J }\end{array}$ & $\begin{array}{l}\text { Increasing observational learning of } \\
\text { children with autism: a preliminary } \\
\text { analysis }\end{array}$ & $\begin{array}{l}\text { J Appl Behav Anal } \\
\text { 2012;45:815-820 }\end{array}$ & 3 children & $\begin{array}{l}\text { Monitoring responses on the acquisition of } \\
\text { sight words with vocal imitation. Participants } \\
\text { read the words with more efficiency in } \\
\text { monitoring sessions. }\end{array}$ \\
\hline
\end{tabular}


Table 2 (continued)

\begin{tabular}{|c|c|c|c|c|}
\hline Authors & Title & Reference & Participants & Proposals and Conclusions \\
\hline $\begin{array}{l}\text { Mims P, Hudson M, } \\
\text { Browder D }\end{array}$ & $\begin{array}{l}\text { Using read-alouds of grade-level } \\
\text { biographies and systematic } \\
\text { prompting to promote } \\
\text { comprehension for students with } \\
\text { moderate and severe developmental } \\
\text { disabilities }\end{array}$ & $\begin{array}{l}\text { Focus Autism Other Dev } \\
\text { Disabl 2012;27:67-80 }\end{array}$ & 4 children & $\begin{array}{l}\text { A modified system of least intrusive prompts } \\
\text { on text-dependent listening comprehension. } \\
\text { All students improved listening } \\
\text { comprehension. }\end{array}$ \\
\hline $\begin{array}{l}\text { Stringfield S, Luscre } \\
\text { D, Gast DL }\end{array}$ & $\begin{array}{l}\text { Effects of a Story Map on } \\
\text { Accelerated Reader postreading test } \\
\text { scores in students with high- } \\
\text { functioning autism }\end{array}$ & $\begin{array}{l}\text { Focus Autism Other Dev } \\
\text { Disabl 2011;26:218-229 }\end{array}$ & 3 children & $\begin{array}{l}\text { Children were taught to use a Story Map as a } \\
\text { postreading organizing tool. Positive effects } \\
\text { were quick and maintained during the study. }\end{array}$ \\
\hline $\begin{array}{l}\text { Travers J, Higgins K, } \\
\text { Pierce T, et al. }\end{array}$ & $\begin{array}{l}\text { Emergent literacy skills of } \\
\text { preschool students with autism: a } \\
\text { comparison of teacher-led and } \\
\text { computer-assisted instruction }\end{array}$ & $\begin{array}{l}\text { Educ Train Autism Dev } \\
\text { Disabil 2011;46:326-338 }\end{array}$ & 4 children & $\begin{array}{l}\text { Teaching literacy skills to young children with } \\
\text { ASD. Comparing traditional teaching and } \\
\text { multimedia computer assisted instruction. In } \\
\text { both groups children showed improvement. }\end{array}$ \\
\hline $\begin{array}{l}\text { Dogoe M, Banda D, } \\
\text { Lock R, et al. }\end{array}$ & $\begin{array}{l}\text { Teaching generalized reading of } \\
\text { product warning labels to young } \\
\text { adults with autism using the } \\
\text { constant time delay procedure }\end{array}$ & $\begin{array}{l}\text { Educ Train Autism Dev } \\
\text { Disabil 2011;46:204-213 }\end{array}$ & 2 adults & $\begin{array}{l}\text { Constant time delayed to improve reading } \\
\text { skills in learning how to read warning labels. } \\
\text { Both participants acquired the trained skills } \\
\text { but didn't generalize across settings. }\end{array}$ \\
\hline Axe J, Sainato D & $\begin{array}{l}\text { Matrix training of preliteracy skills } \\
\text { with preschoolers with autism }\end{array}$ & $\begin{array}{l}\text { J Appl Behav Anal } \\
\text { 2010;43:635-652 }\end{array}$ & 4 children & $\begin{array}{l}\text { Matrix model with some multiword phrases } \\
\text { are taught and other emerge. Three } \\
\text { participants performed the trained actions. }\end{array}$ \\
\hline
\end{tabular}

${ }^{a}$ Number of subjects not indicated.

the improvement of reading comprehension, as opposed to the studies regarding the use of behavioral techniques to increase single-word reading abilities. However, there is not enough data about the duration of the intervention processes, specific characteristics of the participants before the intervention, training of the therapists in the area, specific material or resources used to allow hypotheses about better or more successful intervention methods.

Literacy acquisition in children and adults with ASD demand further assessment. The large individual varia- tions of the autism spectrum may be reflected in the reading performance of persons with ASD, therefore resulting either in hyperlexia or in different forms of reading deficits. The identification of different reading strategies and specific profiles of abilities and impairments depends on efficient assessment tools that are essential to the design of more efficient intervention procedures. 


\section{References}

1 Klauck SM: Genetics of autism spectrum disorders. Eur J Hum Genet 2006;14:714-720.

2 Oberman LM, Ramachandran VS: The simulating social mind: the role of the mirror neuron system and simulation in the social and communicative deficits of autism spectrum disorders. Psycholog Bull 2007;133:310-327.

3 Di Martino A, Ross K, Uddin LQ, Sklar AB, Catellanos X, Milham MP: Functional brain correlates of social and nonsocial processes in autism spectrum disorders: an activation likelihood estimation meta-analysis. Biol Psychiatry 2009;65:63-74.

4 Geschwind DH: Genetics of autism spectrum disorders. Trends Cogn Sci 2011;15:409-416.

5 Bromley J, Hare DJ, Davison K, Emerson E: Mothers supporting children with autistic spectrum disorders: social support, mental health status and satisfaction with services. Autism 2004;8:4409-4423.

6 Posserud M, Lundervold AJ, Lie SA, Gillberg C: The prevalence of autism spectrum disorders: impact of diagnostic instrument and non-response bias. Soc Psychiatry Psychiatr Epidemiol 2010;45:319-327.

7 Harms MB, Martin A, Wallace G: Facial emotion recognition in autism spectrum disorders: a review of behavioral and neuroimaging studies. Neuropsychol Rev 2010;20:290322.

8 Bellini S, Peters JK, Benner L, Hopf A: A metaanalysis of school-based social skills interventions for children with autism spectrum disorders. Remedial Spec Educ 2007;28:153-162.

9 Kim YS, Leventhal BL, Koh YJ, Fombonne E, Laska E, Lim EC, Cheon KA, Kim SJ, Kim YK, Lee HK, Song DH, Grinker RR: Prevalence of autism spectrum disorders in a total population sample. Am J Psychiatry 2011;168:904-912.
10 Higgins DJ, Bailey SR, Pearce JC: Factors associated with functioning style and coping strategies of families with a child with an autism spectrum disorder. Autism 2005;9:125137.

11 Lecavalier L, Seone S, Wiltz Z: The impact of behaviour problems on caregiver stress in young people with autism spectrum disorders. J Intellect Disabil Res 2006;50:172-183.

12 McConachie H, Diggle T: Parent implemented early intervention for young children with autism spectrum disorder: a systematic review. J Eval Clin Pract 2007;1:120-129.

13 Warren Z, McPheeters ML, Sathe N, FossFeig JH, Glasser A, Veenstra-VanderWeele JA: Systematic review of early intensive intervention for autism spectrum disorders. Pediatrics 2011;127:1303-1311.

14 Risi S, Lord C, Gotham K, Corsello C, Chrysler C, Szatmari P, Cook EH Jr, Leventhal BL, Pickles A: Combining information from multiple sources in the diagnosis of autism spectrum disorders. J Am Acad Child Adolesc Psychiatry 2006;45:1094-1103.

15 Simonoff E, Pickles A, Charman T, Chandler S, Loucas T, Baird G: Psychiatric disorders in children with autism spectrum disorders: prevalence, comorbidity, and associated factors in a population-derived sample. J Am Acad Child Adolesc Psychiatry 2008;47:921929.

16 Howlin P: Autism spectrum disorders. Psychiatry 2006;5:320-324.

17 Lord C, Bishop E, Somer L: Autism spectrum disorders diagnosis, prevalence, and services for children and families. Soc Policy Rep 2010; 24:1-22.
18 Frazier TW, Youngstrom EA, Speer L, Embacher R, Law P, Constantino J, Findling RL, Hardan AY, Eng C: Validation of proposed DSM-5 criteria for autism spectrum disorder. J Am Acad Child Adolesc Psychiatry 2012;51: 28-40.

19 McPartland JC, Reichow B, Volkmar FR: Sensitivity and specificity of proposed DSM-5 diagnostic criteria for autism spectrum disorder. J Am Acad Child Adolesc Psychiatry 2012;51:368-383.

20 Ehlers S, Gillberg C, Wing L: A Screening questionnaire for Asperger syndrome and other high-functioning autism spectrum disorders in school age children. J Autism Dev Disord 1999;29:129-141.

21 Baird G, Simonoff E, Pickles A, Chandler S, Loucas T, Meldrum D, Charman T: Prevalence of disorders of the autism spectrum in a population cohort of children in South Thames: the Special Needs and Autism Project (SNAP). Lancet 2006;368:210-215.

22 Blumberg SJ, Bramlett MD, Kogan MD, Schieve LA, Jones JR, Lu MC: Changes in prevalence of parent-reported autism spectrum disorders in school-aged U.S. children: 2007 to 2011-2012. Natl Health Stat Rep 2003;65:1-7.

23 Grigorenko EL, Klin A, Volkmar F: Annotation: hyperlexia: disability or superability? J Child Psychol Psychiatry 2003;44:1079-1091.

24 Zuccarello R, Biasi FD, Zingale M, Panerai M, Finocchiaro M, Trubia G, Buono S, Zoccolotti P: Reading decoding and comprehension in children with autism spectrum disorders: evidence from a language with regular orthography. Res Autism Spectr Disord 2015;17:126134 